\title{
TOXIC AND HAZARDOUS WASTE (B3) MANAGEMENT AT PT. PAL INDONESIA (PERSERO)
}

\author{
Nurlina \\ Department of Environmental Health \\ Faculty of Public Health, Airlangga University, Surabaya, Indonesia \\ Correspondence Address: Nurlina \\ Email: nurlina-2015@fkm.unair.ac.id
}

\begin{abstract}
PT. PAL Indonesia (Persero) is a state-owned enterprise (BUMN) engaged in the shipbuilding industry. Disposal of hazardous and toxic waste (B3) produced by PT. PAL Indonesia can cause negative impacts on the environment and health if special handling procedures are not taken. In order to avoid this, PT. PAL Indonesia (Persero) carries out B3 waste management. The purpose of this study was to provide an overview of the implementation of B3 waste management in PT. PAL Indonesia (Persero), including identification of B3 waste, packaging and labeling B3 waste, storage, collection and transportation of B3 waste. The research method used was the qualitative descriptive method with data collection techniques of observation, interviews, and documentation. The instrument in this study was a questionnaire. The results of the study show that in the production process, PT. PAL Indonesia (Persero) produced hazardous and toxic (B3) waste in the form of solid and liquid B3 waste in the form of used TL lamps, contaminated cotton waste, silica sand from sand blasting processes, used oil, and sludge oil. The B3 waste contained heavy metals such as $\mathrm{Pb}, \mathrm{Cu}, \mathrm{Hg}, \mathrm{Fe}$, and $\mathrm{Zn}$. The conclusion of this research is that the implementation of B3 waste management in PT. PAL Indonesia (Persero) has not complied with implemented regulations. This study suggests the supervision of B3 waste management in PT. PAL Indonesia (Persero) as well as increased awareness of workers to wear protective equipment in managing B3 waste.
\end{abstract}

Keyword: B3 waste management, PT. PAL Indonesia (Persero), B3 waste content.

\section{INTRODUCTION}

Industrial waste can be categorized based on its characteristics. There are three kinds of waste: liquid waste, solid waste, and gaseous waste (Darmono, 2001). Liquid waste is the remains from businesses or practices that is in the form of liquids and water, along with residues that are suspended or mixed in the water. Solid waste is the remains that are in the form of solid materials. Gaseous waste, meanwhile, is air pollution that is in the form of substances, organisms, or energy inserted into the air by means of human activities or natural occurrences, which results in air quality decreasing and dropping down to the point where it cannot be used in ways that it is supposed to be used.
Problems regarding waste management can promote environmental pollution. The pollution process by toxic and hazardous waste, especially in shipyard construction industries, can occur directly and indirectly. The process directly impacts poisoning and disrupts the health of humans, animals, and plants or disturbs the ecological balance of water, air, and soil through pollution. The impact of pollution can be in the form of acute illness or chronic disease that will be felt after a certain period. In overcoming the emergence of pollution, nature has its own ability to overcome these problems (self recovery), but with limitations. When these limits are exceeded, then pollution will be in nature permanently or accumulate and have an impact on humans, 
material, animals, plants, and ecosystems (Ginting 2007)

Environmental pollution in the form of residual industrial products requires special attention from the government, businesses, and the community. Disposal of industrial waste is a problem that needs to be addressed appropriately and quickly, especially if the waste contains certain chemical compounds such as hazardous and toxic materials.

According to RI Law No. 23/1997 concerning Environmental Management, B3 waste is the residue of a business and/or activity that contains hazardous and/or toxic materials, which, due to their nature and/or concentration and/or amount, may directly or indirectly pollute and/or damage the environment and/or endanger the environment, health, human survival, and other living things. Meanwhile, according to Watts (1997) in Mukhlishoh (2012), B3 waste is defined as solid waste or a combination of solid waste. Due to the amount, concentration, physical, chemical or infectious nature that can cause death and illness, the substance can be harmful to human health and the environment due to improper management, be it storage, transportation, or disposal.

Government Regulation No. 101 of 2014 concerning Management of Hazardous and Toxic Waste states that the category of B3 waste was divided into the following categories: 1) B3 waste that has an acute and direct impact on humans and will certainly have a negative impact on the environment; 2) B3 waste that has a delayed effect, and has an indirect impact on humans and the environment and has sub-chronic or chronic toxicity. B3 waste sources are divided into non-specific sources, namely B3 waste which generally does not originate from the main process. Rather, it comes from activities such as tool maintenance, washing, prevention, corrosion or corrosion inhibitors, scale dissolution, and packaging. Specific sources are B3 waste left over from an industrial process or activity that can be specifically determined.

Characteristics of B3 waste according to Government Regulation No. 101 of 2014 concerning Management of Hazardous and Toxic Waste mentions the characteristics of B3 waste as explosive, flammable, reactive, infectious, corrosive, and toxic.

The effects of B3 waste on health include interference with breathing. This is because high vapor concentrations will be dangerous if inhaled. High concentrations can interfere with the respiratory tract (nose, throat, and lungs), causing nausea, vomiting, headaches, dizziness, loss of coordination, taste, and other neurological disorders. Exposure to acute concentrations can cause nervous depression, fainting, coma, and/or death. Moreover, it can cause irritation to the eyes and skin. That is because B3 waste causes dermatitis or seeps into the skin and causes an impact on breathing. It also affects digestion since $\mathrm{B} 3$ waste in the digestive tract is dangerous if swallowed, causing nausea, vomiting, and other neurological disorders, lung cancer, and even death (Ginting, 2007).

Dutta, et al. (2006) has mentioned that the health effects of hazardous waste, such as heavy metals containing lead, include interference with lead poisoning, neurtotoxic, mental disorders, brain, kidney, and liver damage. Medical conditions that are exacerbated by exposure to high concentrations include disorders of the heart, liver, kidneys, respiratory tract (nose, throat, lungs), central nervous system, eyes, and skin.

Cases of waste disposal of hazardous and toxic materials (B3) as a source of pollution and environmental damage by industrial output units have increased significantly, especially in rapidly developing industrial regions such as ASEAN countries and China. The release of hazardous materials since the 1990s in Indonesia, Thailand, and the Philippines is estimated to have increased 
to between 4.8-10 times. It is estimated that more than $85 \%$ of industries in Java and $70 \%$ of industries located in urban areas and its surroundings (Jakarta, Surabaya, Bandung, and Semarang) have the potential to produce hazardous waste at approximately 200,000 tons in 1990 to 1 million tons in 2010 (Demanhuri, 2010). The increase in B3 waste yields in the industry is quite large, thus an integrated and continuous system is needed to avoid the effects caused by B3 waste.

Ichtiakhiri and Sudarmaji (2015) mention that the B3 waste management carried out by PT. INKA (Persero) has not fulfilled the requirements in its selection and storage. Health complaints that are often felt by B3 waste management workers are headaches and skin irritation. The generation of B3 waste from industrial products is increasingly feared to have a wider impact on human health and the quality of the environment caused by pollution of hazardous and toxic materials. To prevent and/or reduce these impacts, an integrated and sustainable management system is needed (Azteria and Efendi, 2017). The Republic of Indonesia Government Regulation No. 101 of 2014 concerning Management of Hazardous and Toxic Material Waste states that B3 waste management is an activity that includes reduction, storage, collection, transportation, utilization, processing, and/or temporary storage area.

PT. PAL Indonesia (Persero) is a state-owned enterprise (SOE) company engaged in the shipbuilding industry. Producing various kinds of products does not escape the results of their waste in every production process. The resulting waste can be in the form of hazardous and toxic material (B3), which has the potential to pollute the environment.

The types of B3 waste generated at PT. PAL Indonesia (Persero) include solid B3 waste, namely used TL lamps, contaminated cotton waste, and silica sand from the sand blasting process. Their liquid B3 waste is used oil and sludge oil. The B3 waste has toxic, corrosive, and combustible properties. B3 waste in PT. PAL Indonesia (Persero) also contains various heavy metals such as $\mathrm{Pb}, \mathrm{Cu}$, $\mathrm{Hg}$, and $\mathrm{Fe}$.

B3 waste generated by PT. PAL Indonesia (Persero) has the potential to be hazardous to health and the environment because they contain hazardous chemicals such as used TL lamps containing mercury. Used oil, contaminated cotton waste, sludge oil containing hydrocarbons include toluene, ethylbenzene, xylenes, and lead heavy metals. Used oil, in addition to containing chemicals including hydrocarbons and sulfur, also contain other chemicals such as fuel residue, copper, aluminum iron, magnesium, and nickel. This is because the oil works lubricate the engine. B3 waste also comes from dust blasting, since sand blasting contains heavy metals such as copper and iron. The amount of waste released in each production division depends on the amount of production produced and the type of production. Waste that is discharged directly into the environment without any prior processing will certainly increase the volume of B3 waste at the disposal site.

In an effort to minimize environmental damage and negative impacts caused, PT. PAL Indonesia (Persero) has managed the B3 waste produced. B3 waste management in PT. PAL Indonesia (Persero) includes identification of B3 waste, packaging of B3 waste, storage of B3 waste, collection of B3 waste, reporting, and transportation of B3 waste.

This study aimed to describe the implementation of B3 waste management in PT. PAL Indonesia (Persero).

\section{METHODS}

This is a qualitative descriptive study which provides a systematic, factual, and accurate picture of the facts and nature of 
individuals, circumstances, or symptoms of certain groups.

This research was conducted at PT.

PAL Indonesia (Persero). The aspect observed in this study was the B3 waste management system at PT. PAL Indonesia (Persero) including identification of B3 waste, packaging and labeling B3 waste, storage of B3 waste, collection of B3 waste, transportation of B3 waste, and reporting of B3 waste in accordance with Government Regulation No. 101 of 2014 concerning Management of Hazardous and Toxic Waste.

Data collection techniques were done using primary data and secondary data. Primary data were obtained from in-depth interviews and temporary storage area observation processes using questionnaires and observation sheets. Secondary data were obtained through literature review and Standard Operational Procedure (SOP) of B3 waste management at PT. PAL Indonesia (Persero). This study was approved by the Health Research Ethics Committee with Certificate Number of 264/HRECC.FODM/V/2019.

\section{RESULTS}

\section{General Description of PT. PAL Indonesia (Persero)}

PT. PAL Indonesia (Persero) is one of the strategic industries that produces the main tools of Indonesia's defense system especially for the sea dimension. Its existence certainly has an important and strategic role in supporting the development of the national marine industry. Establishment of PT. PAL Indonesia (Persero) started from a shipyard named MERINE ESTABILISHMENT and was founded by the Dutch government in 1939. During the Japanese occupation, the company changed its name to Kaigun SE 2124.

After Indonesian gained independence, the Indonesian government socialized this company and changed its name to Navy Upgrading (PAL). On April 15, 1980 based on Government Regulation No. 4 of 1980, the company status of PT. PAL Indonesia (Persero) changed from a public company to a Limited Liability Company in accordance with deed Number 12 by Notary Hadi Moentoro, SH.

The vision of PT. PAL Indonesia (Persero) is to be a world-class maritime and energy industry construction company. While the mission carried by PT. PAL Indonesia (Persero) is building, maintaining, and providing engineering services for upper and subsurface vessels and engineering procurement and construction in the field of energy, as well as providing integrated services that are environmentally friendly for customer satisfaction, and building the independence of the defense and security industry of the sea, maritime, and energy dimensions. Based on its vision and mission, PT. PAL Indonesia (Persero) works hard to deliver knowledge, skills, and technology to the wider community of the national maritime industry. This effort has become relevant as a key holder to improve the national maritime industry. PT. PAL Indonesia (Persero) is located in the city of North Surabaya, precisely at the tip of Surabaya and in the Navy base region for the eastern region.

Products produced by PT. PAL Indonesia (Persero) include commercial ship products, fast ship and special ship products, service (Harkan) products, and general engineering products. They have bulk carriers (bulkers) of up to 50,000 DWT, a landing platform dock 125 meters long, and class aluminum hull ships of up to 38 meters. They also cover product maintenance and repair services to the depot level with a docking capacity of 894,000 DWT per year, steam turbine assembly of up to $600 \mathrm{MW}$, and the balance of plant and boiler components of up to $600 \mathrm{MW}$. 


\section{B3 Waste Identification of PT. PAL Indonesia (Persero)}

Sources of hazardous waste generated by PT. PAL Indonesia (Persero) originates from production units such as the commercial ship division, the warship division and the maintenance and repair division and offices. B3 waste generated in each production and office division is based on a number of activities carried out. An example is the used TL lamps generated from office and workshop activities that are used as lighting sources. There is also contaminated cotton waste resulting from oil cleaning, dusting, and painting activities. Sand blasting is the process of cleaning the surface by firing particles (sand) onto a material surface with abrasive material in the form of silica sand with high pressure to remove contaminated material such as rust, paint, salt, and attached oil. In addition, it also aims to make roughness on metal surfaces to ease paint glue and repair and cleaning on oil tank vessels. Oil sludge comes from cleaning tanks in the form of lumps instead of pure oil.

Table 1. B3 Waste Identification of PT. PAL Indonesia (Persero)

\begin{tabular}{llccccc}
\hline No & B3 Waste & $\begin{array}{c}\text { B3 Waste } \\
\text { Type }\end{array}$ & $\begin{array}{c}\text { B3 Waste } \\
\text { Properties }\end{array}$ & $\begin{array}{c}\text { B3 } \\
\text { Waste } \\
\text { Codes }\end{array}$ & $\begin{array}{c}\text { Danger } \\
\text { Category }\end{array}$ & $\begin{array}{c}\text { Source } \\
\text { Category }\end{array}$ \\
\hline 1. & Used lubricating oil & $\begin{array}{c}\text { Liquid B3 } \\
\text { waste }\end{array}$ & Flammable & B105d & 2 & Unspecified \\
\hline 2. & $\begin{array}{l}\text { Contaminated cotton } \\
\text { waste }\end{array}$ & $\begin{array}{c}\text { Solid B3 } \\
\text { waste }\end{array}$ & Flammable & B110d & 2 & Unspecified \\
\hline 3. & Used TL lamps & $\begin{array}{c}\text { Solid B3 } \\
\text { waste }\end{array}$ & Toxic & B107d & 2 & Unspecified \\
\hline 4. & Sludge oil & $\begin{array}{c}\text { Liquid B3 } \\
\text { waste }\end{array}$ & Flammable & B105d & 2 & Unspecified \\
\hline $\mathbf{5 .}$ & Sand blasting & $\begin{array}{c}\text { Solid B3 } \\
\text { waste }\end{array}$ & $\begin{array}{c}\text { Toxic, } \\
\text { Corrosive }\end{array}$ & B102d & 2 & Unspecified \\
\hline
\end{tabular}

Source: PT. PAL Indonesia (Persero), 2019

Table 1 shows that $\mathrm{B} 3$ waste produced by PT. PAL Indonesia (Persero) are solid B3 waste and liquid B3 waste, namely TL lamps, contaminated cotton waste, silica sand from the sand blasting process, used lubricating oil/used oil, and sludge oil with flammable, toxic, and corrosion waste properties. B3 waste generated by PT. PAL Indonesia (Persero) is included in category 2 which means that waste containing B3 has an indirect impact on humans and the environment, has a delayed effect, and has sub-chronic or chronic toxicity. Non-specific waste refers to B3 waste which generally does not originate from the main process.

\section{Packaging, Labelling, and B3 Waste} Symbols of PT. PAL Indonesia (Persero)

B3 waste packaging activities at PT. PAL Indonesia (Persero) is handled by the relevant Health Safety Environment (HSE) in each production division by providing $\mathrm{B} 3$ waste containers based on the type and characteristics of B3 waste. Solid B3 waste packaging is as follows: used TL lamps utilize safe boxes, sand blasting utilize sack packaging, contaminated cotton waste utilize 200 liter iron drums, while packaging for used oil liquid B3 waste and sludge oil utilize iron drums with 200 liter capacity and intermediate bulk containers (IBC) with a capacity of 1,000 liters. 
The safe box packaging material is made of metal made of steel and cannot react with the B3 waste that is stored and is safe against corrosion and not easily damaged. Packaging conditions were in good condition, with no rust or leaks. Sacks are used as solid B3 waste packaging for silica sand produced from the sand blasting process because it has the characteristics of corrosive and solid packaging. The sack packaging was in good condition and did not leak. This sack pack had a capacity of 1 ton.

The iron drum packaging is made of metal made of steel and cannot react with B3 waste that is stored and is safe against corrosion, meaning the tank or drum packaging could not be easily damaged. The condition of the iron drum in the temporary storage area of the production division was not good, damaged, and rusty, making it easier for spills or leakage of B3 waste outside the packaging.

The IBC packaging is made of high density polyethylene (HDPE) as one of the recommended plastic materials for use because of its ability to prevent chemical reactions between stored materials and palettes. In all B3 waste packaging in the B3 waste temporary storage area production division, the sticking of symbols and labels as markers on the packaging had not been done as a whole.

\section{B3 Waste Storage of PT. PAL Indonesia (Persero)}

B3 waste storage is carried out at each temporary storage area production division of PT. PAL Indonesia (Persero). B3 waste storage is located outside or inside a B3 waste-producing building. One of the hazardous waste storage areas was found to not meet applicable regulations, namely the temporary storage area of the maintenance and repair division (Harkan).

The condition of the temporary storage area building of this division was only in the form of a roof, iron barrier, and walls of buildings that did not cover the temporary storage area as a whole. This facilitates the entry of rain and sunlight into the temporary storage area. The condition of the building floor was cracked and uneven. There were liquid B3 waste spills due to the use of damaged B3 waste packaging. There were no drainage channels or storage tanks, which could have caused liquid B3 waste to spread easily to the environment.

The B3 waste temporary storage area building PT. PAL Indonesia (Persero) was equipped with a lightning protection system and the outer side of the B3 waste temporary storage area building was symbolized in accordance with applicable regulations, had adequate ventilation, and was without a ceiling. The lighting system utilizing sunlight and the placement of lamps installed $>1$ meter above the storage package. The outside of the B3 waste temporary storage area was marked with the B3 symbol B3. The roof, walls, ventilation, and gauze were in a damaged condition. There was inundation on the B3 waste temporary storage area floor. The condition of the floor was bumpy, not strong, and cracked. The switches were located on the inside of the building.

The storage time of solid B3 waste at each B3 waste temporary storage area was carried out every two months because the B3 waste produced by PT. PAL Indonesia (Persero) was less than $50 \mathrm{~kg} /$ day. Meanwhile, liquid B3 waste, namely used oil and sludge oil for long-time storage, was carried out every 1-2 days and transported to the main B3 waste temporary storage area.

\section{Collection of B3 Waste of PT. PAL Indonesia (Persero)}

The collection of B3 waste was carried out by transporting B3 waste from the production division temporary storage area to the main B3 waste temporary storage area. The main temporary storage area of B3 waste 
had its roofs, walls, vents, and gauze in a damaged condition. Sunlight and rain water could have easily entered the B3 waste temporary storage area. The entry of rain water into the main B3 waste temporary storage area caused a puddle of water on the B3 waste temporary storage area floor, causing a bumpy, unstable, and cracked floor. A stop (stop contact) was also placed on the inside of the main B3 waste temporary storage area building.

In the process of transporting B3 waste in the B3 waste temporary storage area, spills and scattered oil and sludge oil in the B3 waste temporary storage area had the potential to pollute the environment and pose health risks to B3 waste management workers. This is because the lead content was found in used oil and sludge oil and the driver did not use personal protective equipment (PPE) such as masks, safety helmets, safety googles, and gloves.

After the B3 waste has been collected, it is then stored for 180 days in the main B3 temporary storage area, then handed over to the B3 waste user or temporary storage area. The placement of B3 waste packaging at the main temporary storage area of B3 waste was done with a block and separate system. In the main temporary storage area of B3 waste, there were facilities such as fire fighting equipment and systems, first aid facilities (P3K, APAR, eye wash), warehouses, and emergency exits

\section{B3 Waste Transportation of PT. PAL Indonesia (Persero)}

Internal B3 waste transportation was carried out by special officers who had an operator license (SIO) from the manpower office using forklifts and cars. While the removal of B3 waste externally was carried out by a third party B3 waste transportation agency to the users, processors, and temporary storage areas of B3 waste.
B3 waste transportation was carried out by a third party B3 waste transportation service and with a license certificate from the Indonesian Ministry of Environment. This is in accordance with the requirements because the transportation of B3 waste produced must have a transportation permit from the minister of transportation after obtaining a recommendation from the head of the responsible agency. The transportation system carried out by a third party used a special conveyance in an open condition accompanied by a warning sign.

\section{B3 Waste Reporting}

Reporting was carried out by the zone division as the division that was authorized in the activities of recording B3 waste, making B3 waste balance sheets, and reporting B3 waste documents. B3 waste document reporting activities were carried out to external parties, namely the Indonesian Ministry of Environment, the Provincial Environmental Agency, and the Surabaya City Environmental Agency every three months.

\section{DISCUSSION}

\section{B3 Waste Identification of PT. PAL Indonesia (Persero)}

TL lamps are glass-shaped and contain mercury with neurotoxin/toxic properties that are very dangerous and can affect the brain and kidneys. MSDS (2016) explains that TL lamps have the potential danger to human health and the environment if dropped or broken because of the mercury content in it. Mercury can enter the body through the respiratory system. Due to the volatile nature of mercury, this can cause poisoning effects on the central nervous system that cause seizures, difficulty of breathing, and loss of consciousness. If swallowed, it causes stomach aches, nausea, vomiting, and diarrhea. Eye contact has the risk of serious damage to eyes and it is highly 
toxic to aquatic life with long lasting effects. Other negative effects are circulatory failure, drop in blood pressure, cardiac arrhythmias, and kidney disorders.

Silica sand waste produced from the sand blasting process is included in the hazard category 1 because it contains heavy metals, namely copper $(\mathrm{Cu})$ and iron $(\mathrm{Fe})$. Silica dust can pose a potential hazard when cutting, blasting, or other processes occur because it produces smaller sized particles, known as silica dust. The presence of silica dust in the work environment when inhaled by workers is very dangerous for the respiratory tract because it can damage the lungs that lead to respiratory diseases such as silicosis, bronchitis, and asthma. Symptoms felt by someone when exposed to silica dust are severe coughing, chest pain, shortness of breath and fatigue, eye irritation, and corneal damage. Exposure to silica dust and silicosis increase the risk of lung cancer, tuberculosis, and chronic obstructive pulmonary disease (Mzurti and Ibrahim, 2018).

Used lubricating oils, sludge oil and contaminated cotton cloth contain hydrocarbons including toluene, ethylbenzene, xylenes, and heavy lead metals. Heavy metals that are discharged into the environment without recycling will endanger both land and water ecosystems because of its non-biodegradable nature (Jodeh, et al., 2015). In addition, the chemical content of hydrocarbons and sulfur in used lubricating oil also contains residual fuel chemicals such as aluminum, iron, copper, nickel, and magnesium. Lead toxicity can be chronic or acute. Chronic lead exposure can result in fatigue, lethargy, irritability disorders, gastrointestinal disorders, headaches, impaired memory, depression, and difficulty sleeping. Acute exposure can occur if lead ingresses into one's body through food or by inhaling high doses of lead gas (Widowati, Sastiono, and Reymond, 2008).

\section{Packaging, Labelling, and B3 Waste Symbols of PT. PAL Indonesia (Persero)}

The packaging material used at PT. PAL Indonesia (Persero) has a requirement that it does not react with B3 waste stored therein. This is in accordance with the packaging standards in Indonesia as stipulated in the Decree of the Head of Bapedal No. 1 concerning Procedures and Technical Requirements for the Storage and Collection of Hazardous and Toxic Waste.

The type of B3 waste packaging used in the production division temporary storage area has fulfilled the requirements for B3 waste packaging as regulated in Decree of the Head of Bapedal No. 1 of 1995, which states that the form of packaging and packaging materials should be selected according to the type and characteristics of the stored waste and in good condition, undamaged, and not leaking.

Good B3 waste packaging should not leak, be rusty, or be damaged, and have a shape, size, and B3 waste packaging material in accordance with the characteristics of B3 waste that is packaged by considering the safety and ease of handling aspects.

The sticking of symbols and labels on B3 waste packaging was done in the main B3 waste temporary storage area. The production division was not in accordance with Government Regulation No. 14 of 13 concerning B3 Waste Symbols and Labels, which states that the labeling of B3 waste should be carried out on B3 waste packaging.

\section{B3 Waste Storage of PT. PAL Indonesia (Persero)}

One of the temporary storage areas that did not meet the requirements was the temporary storage area division (Harkan) which could not protect the B3 waste stored in it in violation of Government Regulation No. 101 of 2014 concerning Management of Hazardous and Toxic Waste Material Article 16 No. 1 which states that design and 
construction should be able to protect B3 waste from rain and sunlight.

The duration of $\mathrm{B} 3$ waste storage in the temporary storage area in the production division and the main temporary storage area of $\mathrm{Be}$ waste was in accordance with Government Regulation of the Republic of Indonesia No. 101 of 2014 concerning Management of Hazardous and Toxic Material Waste. It states that the B3 waste generated should be $50 \mathrm{~kg} /$ day with a 90 day duration of B3 waste storage after the waste is generated. The unavailability of dikes for liquid B3 waste at the production division temporary storage area makes it easy for liquid waste to be scattered. This is not in accordance with the Head of Bapedal No. 1 of 1995 concerning Procedures for Technical Requirements for the Storage and Collection of Hazardous and Toxic Waste Material, which states that the liquid B3 waste packaging should be surrounded by embankments and a drainage channel leading to the reservoir.

According to Ginting (2007), the entry of B3 waste into the body has an effect on health. When inhaled by humans with high vapor concentration, it can irritate the respiratory tract (nose, throat, and lungs) and cause nausea, vomiting, dizziness, headaches, loss of coordination, taste, and other nerve disorders. Exposure to acute concentrations can result in nerve depression, fainting, coma, and/or death.

\section{Collection of B3 Waste of PT. PAL Indonesia (Persero)}

B3 waste collection is carried out from the production division temporary storage area to the main B3 waste PT. PAL Indonesia (Persero). The B3 waste temporary storage building of PT. PAL Indonesia (Persero) was in accordance with applicable regulations, namely by separating B3 waste based on its type and characteristics as well as the building area of $\mathrm{B} 3$ waste temporary storage area capable of accommodating the amount of B3 waste produced.

The condition of the main temporary storage area of B3 waste was not in accordance with Government Regulation No. 101 of 2014 concerning Management of Hazardous and Toxic Waste Material, which states that the design and construction should be able to protect B3 waste from rain and sunlight and stop contacts should be installed on the outside of the building where temporary B3 waste is stored.

It was found that some workers who did not wear protective equipment while working certainly had a greater risk than workers using PPE (Irmasari, 2018).

Widowati, Sastiono, and Reymond (2008) explained that lead toxicity is chronic and acute. Chronic entry of lead into the body can cause health problems such as lethargy, fatigue, gastrointestinal disorders, irritability disorders, headaches, depression, difficulty concentrating, impaired memory and difficulty sleeping. It is acute if lead enters the body through food in relatively high doses or levels.

The duration of $\mathrm{B} 3$ waste storage in the main temporary storage area of B3 waste was in accordance with Government Regulation No. 101 of 2014 concerning Management of Hazardous and Toxic Waste, stating that the waste produced should be less than $50 \mathrm{~kg} / \mathrm{day}$. B3 waste storage time should be 180 days after the $\mathrm{B} 3$ waste is produced.

The condition of B3 waste packaging in the main temporary storage area of B3 waste namely the use of safe boxes, sacks, iron drums, and IBC was in accordance with the requirements, namely the condition of the packaging in good condition, not leaking, rusty or damaged, shape, size, and material of B3 waste packaging according to the characteristics packaged B3 waste.

In the process of sticking symbols and labels on the $\mathrm{B} 3$ waste packaging in the main temporary storage area, B3 waste was in accordance with the Indonesian Ministry of 
Environment Regulation Number 14 of 2013 concerning the Symbols and Labels of Hazardous and Toxic Waste. Collection and placement of B3 waste packaging at PT. PAL Indonesia (Persero) was in accordance with Decree of the Head of Bapedal No. 1 of 1995 concerning Procedures and Technical Requirements for the Storage and Collection of Hazardous and Toxic Waste.

\section{B3 Waste Transportation of PT. PAL Indonesia (Persero)}

The Department of K3LH as the authorized party in the case of B3 waste management, namely transport of B3 waste, includes documents of B3 waste including road permits and B3 waste manifests to third parties during the process of delivering B3 waste. The delivery of B3 waste is in accordance with the requirements, namely producers, collectors, beneficiaries, and processors for transporters must be accompanied by B3 waste documents.

B3 waste transportation system PT. PAL Indonesia (Persero) by a third party uses a conveyance accompanied by a danger sign that was in accordance with the provisions stipulated in the applicable laws and regulations, namely B3 waste conveyance using open conveyance.

\section{B3 Waste Reporting of PT. PAL Indonesia (Persero)}

B3 waste reporting activities include the B3 waste balance sheet, the B3 waste logbook and the manisfest waste to external parties in accordance with Government Regulation of the Republic of Indonesia No. 101 of 2014 concerning Management of Hazardous and Toxic Waste, which states that the B3 waste storage report should be submitted to the regent or mayor with a copy to the minister at least once every three months after the permit is issued.

\section{CONCLUSION}

PT. PAL Indonesia (Persero) produces B3 waste originating from the offices and production divisions including the commercial ship division, warship division, and maintenance and repair division. The types of waste produced are types of solid B3 waste and liquid B3 waste such as used TL lamps, contaminated cotton waste, silica sand from the sand blasting process, used oil, and sludge oil included in category 2 which are sourced from non-specific and toxic, corrosive, and flammable waste. B3 waste is produced by PT. PAL Indonesia (Persero), namely heavy metals such as mercury $(\mathrm{Hg})$, lead $(\mathrm{Pb})$, copper $(\mathrm{Cu})$, iron $(\mathrm{Fe})$ and zinc (Zn). The implementation of B3 waste management in PT. PAL Indonesia (Persero) was not in accordance with applicable regulations.

Based on the research carried out below, the advice given is, among others, the HSE needs to pay attention and improve the B3 waste management system, especially regarding the packaging used as B3 waste containers based on the type and characteristics in the temporary storage area of each production division. There should also be routine checks once a week on the B3 waste packaging in the temporary B3 waste storage area in accordance with applicable regulations. There should be an improvement of the labels and symbols on the B3 waste packaging in the temporary storage area of each production division. There should also be regular maintenance, checking, and repair of buildings in the B3 waste temporary storage area building periodically to protect B3 packaging and avoid polluting the environment. The placement of switches at the B3 waste temporary storage area should be moved to the outside of the building. They should procure communication equipment, alarms, and generators at the B3 waste temporary storage area in anticipation of an emergency. There should also be 
socialization of the obligation to use PPE to workers who are at risk of exposure to B3 waste in the work area, work rotation of workers, the availability of posters about the danger of B3 waste in the area of B3 waste management, and a general check-up of workers who are exposed to B3 waste every six months.

\section{REFERENCES}

Azteria, V. dan Efendi, J. (2017) 'Identifikasi Keselamatan Penanganan Limbah Pelumas Pada PT. Altrak 1978 Balikpapan', Jurnal Biologi Lingkungan, Industri, Kesehatan, 4(1), pp. 32-40.

Baswedan, S. dan Lilis, S (2015) 'Pengelolaan Kondisi Fisik Lingkungan dan Keluhan Kesehatan Pekerja di Ruang Produksi Garment di Gresik' Jurnal Kesehatan Lingkungan, 8(1), pp.

25-35.

http://dx.doi.org/10.20473/jkl.v8i1.201 5.25-35

Chandra, B. (2007) Pengantar Kesehatan Lingkungan. Jakarta: EGC.

Damanhuri, E. (2012) 'Studi Pengelolaan Limbah B3 (Bahan Berbahaya dan Beracun) Laboratorium Laboratorium di ITB', Jurnal Teknik Lingkungan, 18(April), pp. 12-20. Available at: http://dx.doi.org/10.5614\%2Fjtl.2012. 18.1.2

Darmono (2001) Lingkungan Hidup dan Pencemaran (Hubungan Toksikologi Senyawa Logam). Jakarta: UI Press.

Environmental impact Control Agency. 1995. Keeputusan Kepala Bapedal Nomor 1 Tahun 1995 tentang Tata Cara dan Persyaratan Teknis Penyimpanan dan Pengumpulan Limbah Bahan Berbahaya dan Beracun. Jakarta: Sekretariat Menteri Lingkungan Hidup. Ginting (2007) Sistem Pengelolaan Lingkungan dan Limbah Industri. Bandung: Yrama Widya.
Ichtiakhiri, T. H. dan Sudarmaji (2015) 'Pengelolaan Limbah B3 dan Keluhan Kesehatan Pekerja di PT. Inka (Persero) Kota Madiun', Jurnal Kesehatan Lingkungan, 8(1), pp. 118127. Available at: http://dx.doi.org/10.20473/jkl.v8i1. 2015.118-127

Irmasari, F. (2018) 'Kadar Toluen di Udara Lingkungan Kerja berkorelasi Terhadap Kadar Asam Hipurat Urine Pada Pekerja Percetakan di Rungkut Surabaya', Jurnaal Kesehatan Lingkungan, 10 (3), pp. 328335.

Available

at: http://dx.doi.org/10.20473/jkl.v10i 3.2018.328-335

Jodeh, S., Odeh R., Sawalha M., Obeid, A.A., Salghi R., Hammouti B., Radi S., Warad, I., 2015. Adsroption of Lead and Zinc from Used Lubricant Oil Using Agricultural Soil: Equilibrium, Kinetic and Thermodynamic Studies. J. Mater. Environ. Sci. 6 (2)

Kristanto, P. (2002). Ekologi Industri. Yogyakarta: Andi.

Mukono, J. (2010). Prinsip Dasar Kesehatan Lingkungan . Surabaya: Pusat Penerbit dan Percetakan Unair .

Murti, I. W. and Ibrahim, A. H. (2018) 'Identifikasi Bahaya dan Perancangan Tempat Penyimpanan Sementara (temporary storage area) Limbah B3 Proses Sandblasting di PT Swadaya Graha', ENERGY, 8(1), pp. 1-7.

Ministry of Environment (2009). Peraturan Menteri Lingkungan Hidup Nomor 30 Tahun 2009 tentang Tata Laksana Perizinan dan Pengawasan Pengelolaan Limbah Bahan Berbahaya dan Beracun serta Pengawasan Pemulihan Akibat Pencemaran Limbah Bahan Berbahaya dan Beracun oleh Pemerintah Daerah. Jakarta: Sekretariat Negara

RI Government Regulation. (2013). Peraturan Pemerintah Republik Indonesia Nomor 14 Tahun 2013 
460 The Indonesian Journal of Public Health, Vol 16, No 3 December 2021:449-460

tentang Simbol dan Label Limbah Bahan Berbahaya dan Beracun. Jakarta: Sekretariat Negara Lingkungan Hidup.

RI Government Regulation. (2014). Peraturan Pemerintah Republik Indonesia Nomor 101 Tahun 2014 tentang Pengelolaan Limbah Bahan Berbahaya dan Beracun. Jakarta: Sekretariat Negara.

Rose, K. D. C. dan Tualeka, A. R. (2014) 'Penilaian Risiko Paparan Asap Kendaraan Bermotor Pada Polantas Polrestabes Surabaya Tahun 2014', The Indonesian Journal of Occupational Safety and Health, 3(1), pp. 46-57.

Widowati, W., Sastiono, A. dan Reymond (2008) Efek Toksik Logam. Yogyakarta: Andi. 